\title{
Variability and Experimental Desing for Trials with Cucurbita pepo and Capsicum annuum
}

\author{
Alessandro D. Lúcio ${ }^{1}$, Daniel Santos ${ }^{2} \&$ Tiago Olivoto ${ }^{1}$ \\ ${ }^{1}$ Crop Science Department, Federal University of Santa Maria, Santa Maria, Brazil \\ ${ }^{2}$ São Carlos Center, Federal Institute of Santa Catarina, São Carlos, Brazil \\ Correspondence: Alessandro D. Lúcio, Crop Science Department, Federal University of Santa Maria, Santa Maria, \\ RS 97105-900, Brazil. Tel: 55-55-3220-9499. E-mail: adlucio@ufsm.br
}

Received: August 8, 2017

doi:10.5539/jas.v9n11p58

\author{
Accepted: September 3, 2017 \\ Online Published: October 15, 2017 \\ URL: https://doi.org/10.5539/jas.v9n11p58
}

\begin{abstract}
The variability within rows of cultivation may reduce the accuracy of vegetables trails; however, little is known about this variability in protected environments. This study aimed at to assess the variability in greenhouses cultivated with Cucurbita pepo and Capsicum annuum and to verify the effect of borders use and plot size in minimizing this variability. Data from two uniformity trials each crop were used. For statistical analysis, the total of productivity by plant was used, considering the plants arranged in parallel crop rows the lateral openings of the greenhouse and the same plants arranged in columns perpendicular to these openings. Different scenarios were designed by excluding rows and columns to generate the borders in different plot sizes. For each scenario, a variance homogeneity test was performed among the remaining rows and columns and the variance and coefficient of variation were calculated. There is variability among rows and columns in trials with C. pepo and C. annuum in greenhouses and the use of borders does not bring benefits in terms of reduction of the coefficient of variation or reduction of cases of variances heterogeneity among rows or columns. The use of a plot size greater than or equal to or two plants for trials with C. pepo and ten plants for trials with C. annuum provides homogeneity of variances among rows and columns enabling the use of the completely randomized design.
\end{abstract}

Keywords: heterogeneity, experimental accuracy, experimental design, protected environments

\section{Introduction}

The olericulture is a highly intensive agroeconomic activity that, if properly managed, allows high profitability by area. This activity has been gaining ground in the world production scenario and, in Brazil, the planted area with vegetable crops in 2016 reached 837 thousand hectareswith a total production of 63 thousand tons (CNA, 2017).

Due to the importance of the olericulture, researches are carried out in order to identify factors that favor the quality and productivity of the final product. These researches are conducted through experiments, which must be planned and conducted so that experimental error is as smaller as possible, thus providing quality information to users of search results. For the experimental error to be minimized, it is important to identify the factors that generate variability in the experiment. For example, studies by Webb (1978), Raji, Jannatizadeh, Fattahi, and Esfahlani (2014), Correa et al. (2011), Lúcio, Nunes, Rego, and Pasini (2016), Lindemann-Zutz, Fricke, and Stützel (2016), and Searle, Johnstone, and Reid (2016), have reported different factors that might generate variability in the experiments inflating the experimental error.

The greater the experimental error, the greater the chances of the treatments under study being inadequately discriminated, increasing the probability of occurrence of the type II error (Cochran \& Cox, 1986; Steel, Torrie, \& Dickey, 1997). Thus, for the results of an experiment to be reliable and provide accurate information, it is imperative that the experimental error be as small as possible.

There are several strategies for reducing experimental error. Steel et al. (1997) reported that the experimental error may be minimized by using the following techniques: (i) concomitant observations; (ii) adequate experimental design; and (iii) suitable size and shape of the experimental unit. Storck, Lopes, Estefanel, and Garcia (2016) point out that the determination of plot/sample sizes and the number of replicates are efficient strategies to reduce the experimental error and might be adopted still at the time of experiment planning. 
In experiments with vegetable crops, in addition to soil heterogeneity, some particularities such as the presence or absence of fruits suitable for harvesting, the multiple harvests that are made in some crops, the more intensive cultural management in relation to other cultures and the use of protected environments are additional sources of variability (Lorentz, Lúcio, Boligon, Lopes, \& Storck, 2005; Lúcio et al., 2008). Thus, some of the strategies described above for reducing the experimental error cannot be used due to the space limitation, or even when all those strategies are used, satisfactory results are not obtained.

Studies by Lúcio, Lorentz, Boligon, and Lopes (2006) with Capsicum annuum and Lúcio et al. (2008) and Carpes et al. (2010) with Cucurbita pepo showed that there is variability among the cultivation rows of these crops when grown in protected environment. This variability among rows is due to the fact that the lateral rows are in a differentiated condition of light availability, exposure to winds and soil conditions. The way protected environments are structured suggests that, in addition to row variability, there must be variability in the opposite direction from which the crop rows are arranged, i.e., there is variability among columns perpendicular to the lateral openings of the protected environment. However, no studies were found in the literature confirming the existence of this variability.

The existence of variability among cropping rows has been justifying the use of randomized block design in the experiments with vegetable crops in protected environments, using the cropping row as a block to minimize the effect of variability between rows in the experimental error (Lúcio et al., 2006). However, if the hypothesis of variability among columns arranged in the opposite direction of the rows is true, variability within the blocks may be occurring, inflating the residual variance. In this context, a pioneering and detailed study addressing the variability in protected environments grown with vegetable crops need to be carried out, aiming at fill this gap and allow a better accuracy of future experiments in this situation.

The use of borders in the experimental plots is widely used in field experiments, aiming at reducing interplot competition (Cochran \& Cox, 1986; Steel et al., 1997, Storck et al., 2016). For vegetable crops, no studies were carried out verifying if the use of borders could minimize the interaction of the lateral rows or columns of the greenhouse with the external environment.

Thus, the aim of this study was to assess the variability in protected environments cultivated with Cucurbita pepo and Capsicum annuum and to verify the effect of border use and plot size in minimizing this variability.

\section{Methods}

\subsection{Climatic Conditions, Area Description and Plants Culture}

The study was carried out in the experimental area of the Department of Plant Science, Campus of the Federal University of Santa Maria, Santa Maria, Rio Grande do Sul, Brazil (latitude: $29^{\circ} 42^{\prime} 23^{\prime \prime}$ S, longitude: 53 $43^{\prime} 15^{\prime \prime} \mathrm{W}$ at $95 \mathrm{~m}$ asl.). The climate of the region according to Köeppen's classification is Cfa; temperate rainy type, with rainfall well distributed throughout the year and subtropical from the thermal's point of view (Heldwein, Buriol, \& Streck, 2009). The soil is classified in the Brazilian System of Classification of Soils (EMBRAPA, 2006) as Dystrophic Red Argisol.

The protected environments used in the tests have a Pampean arch with the following dimensions: $2.0-\mathrm{m}$-height lateral post, 3.5-m-height central post, 20-m long and 10-m wide, oriented in a north-south direction. Greenhouse cover was made with $150-\mu \mathrm{m}$-thicknesslow-density polyethylene film (LDPE), and anti-UV additive. In all trials, the ridges (crop rows) were covered with black low-density polyethylene film and were arranged parallel to the lateral openings of the protected environments.

The trials with Cucurbita pepo were carried out in two growing seasons: The first trial (trial 1) was carried out at the summer-autumn growing season, whereas the second trial (trial 2) was carried out at the winter-spring growing season. Both trials were performed using Caserta cultivar. The plants were planted in ridges (cropping rows) spaced at $1 \mathrm{~m}$ where each ridge contained 20 plants spaced at $0.9 \mathrm{~m}$. In these trials, 12 harvests were carried out in which the fresh weight of the fruits was measured. The analysed variable was total fresh mass of fruits during the productive cycle of the crop.

The trials with Capsicum annuum were also carried out in two growing seasons. The first trial (trial 1) was carried out at the autumn-winter growing season, whereas the second (trial 2) at the spring-summer growing season. The used cultivar in both trial was Vidi cultivar. In each trial, ten borders (cultivation rows) spaced at 0.6 $\mathrm{m}$ were used, each with 70 plants spaced at $0.25 \mathrm{~m}$. Five harvests were performed in summer-autumn and four harvests in winter-spring. The analysed variable was the total fresh fruit mass during the productive cycle of crop. 


\subsection{Data Analysis}

For the statistical analyses, was considered the total produced per plant, arranged in $k$-cropping rows $(k=8$ for $C$. pepo and $k=10$ for $C$. annuum), parallel to the lateral openings of the greenhouse, and also the same plants are arranged in $j$-columns perpendicular to the side openings of the greenhouse $(j=20$ for $C$. pepo and $j=70$ for $C$. annuит). For each row and column, the mean, variance and coefficient of variation were calculated, simulating different plot sizes (scenarios), multiple of the number of plants per row. In each scenario, the normality of the data was tested by the Lilliefors test (Sprent \& Smeeton, 2006), then the homogeneity of variances among rows and columns was tested by the Bartlett test (Bartlett, 1937).

In order to verify the border effect in the variability, it was started from the original scenario (J0K0 scenario) and new scenarios were designed by excluding rows and columns in order to create the borders (Figures 1 and 2). One line was simultaneously excluded from each end of the greenhouse, whereas columns were excluded, one by one, simultaneously (Figure 2), at each end of the greenhouse up to $50 \%$ of the available columns be excluded (Figure 1). This procedure was performed on different plot sizes, multiple of the number of plants per cropping row. For each row or column exclusion scenario, combination of row and column exclusions, and for each plot size, a new variance was calculated in each row and column, being Bartlett's test repeated. For each situation, the variance and coefficient of variation of the experiment were also calculated again. Statistical analyses were performed in the statistical software SAEG 9.1 and in the Office Excel application, with 5\% probability of error.

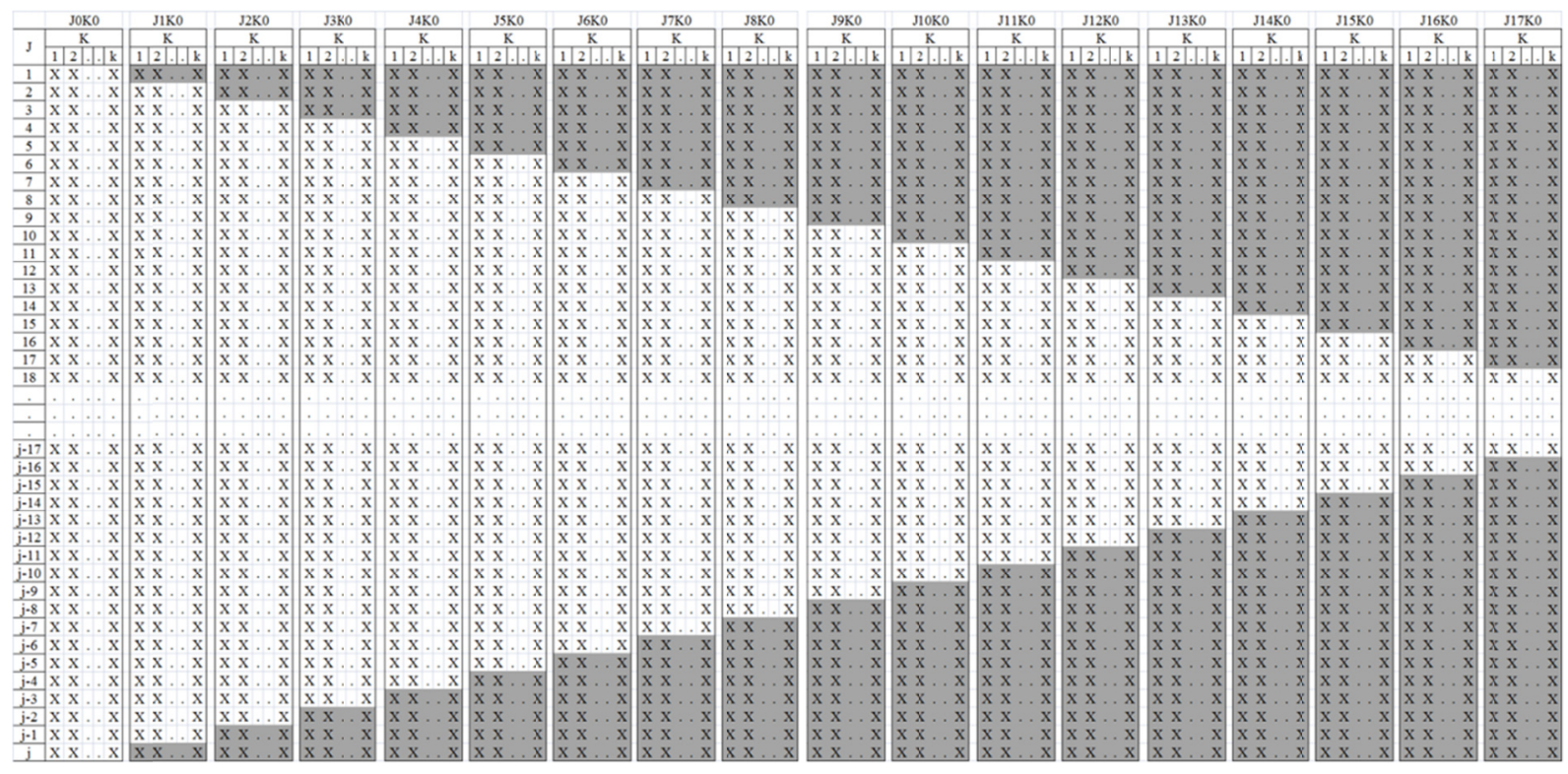

Figure 1. Schematic representation of the plants $(X)$ arranged in rows $(\mathrm{J})$ and columns $(\mathrm{K})$. The scenarios designed by the exclusion of columns are highlighted in gray in the greenhouses grown with C.pepo and $C$. annuum 


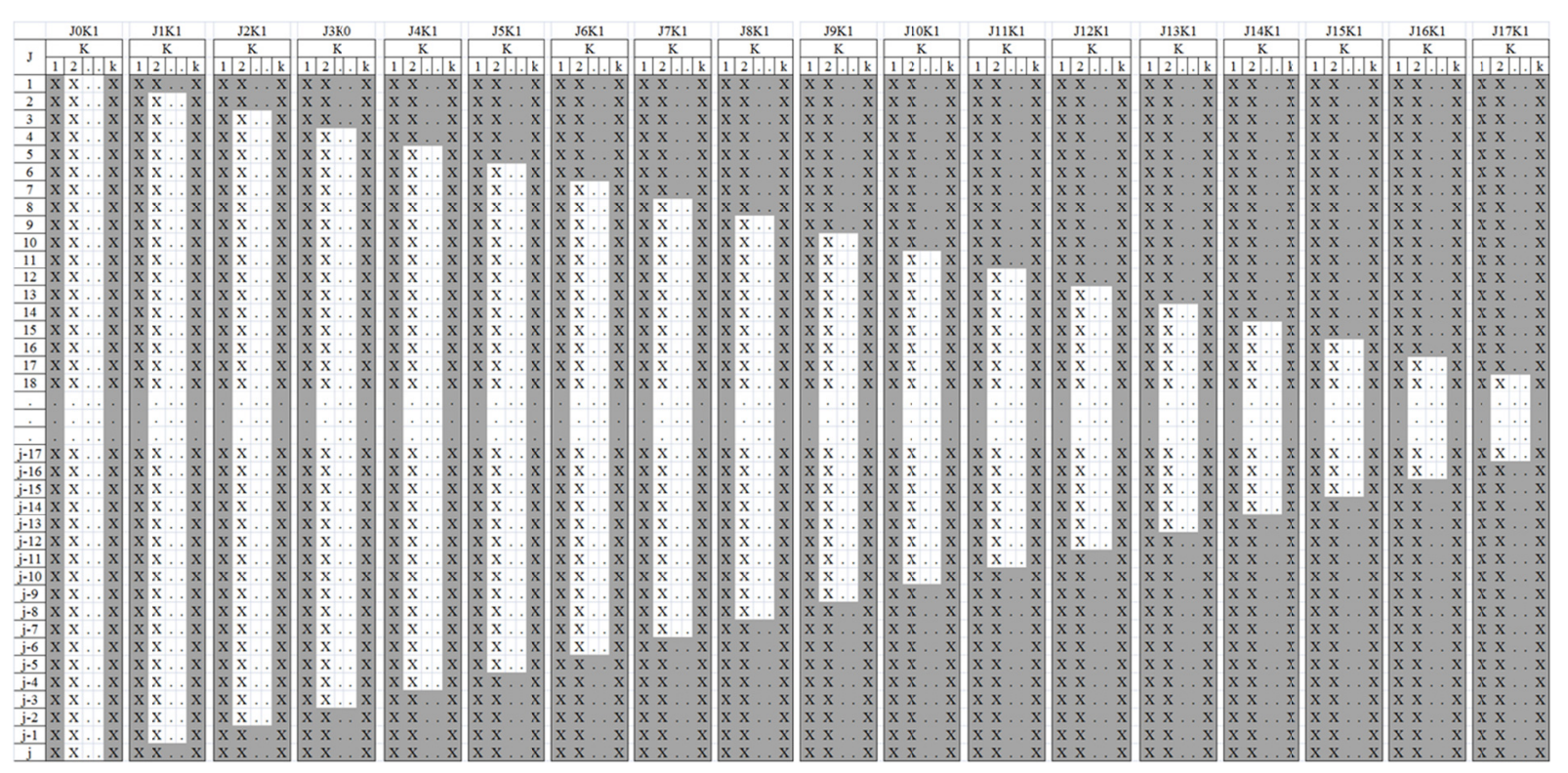

Figure 2. Schematic representation of the plants $(X)$ arranged in rows $(J)$ and columns $(K)$. The scenarios designed by the exclusion of rows and columns are highlighted in gray in the greenhouses grown with C.pepo and $C$. annuum

\section{Results}

Considering the situations where no borders were used (Scenario J0K0), for C. pepo crop, there were cases of variance heterogeneity among rows in $71 \%$ of the cases in the trial 1 (Table 1) and $81 \%$ in the trial 2 (Table 2). For $C$. annuиm crop, however, $75 \%$ of rows have presented heterogeneity of variances in both trials (Tables 3 and 4).

Table 1. Minimum level of significance of the Bartlett's test (\%) among rows of C. pepo in different scenarios created by the exclusion of rows $(\mathrm{K})$ and columns $(\mathrm{J})$, in different experimental unit sizesfor the trial carried out at the summer-autumn season

\begin{tabular}{lllllll}
\hline \multirow{2}{*}{ Scenario $^{\mathrm{a}}$} & \multicolumn{7}{c}{ Size of experimental unit in plants } \\
\cline { 2 - 7 } & 1 & 2 & 3 & 4 & 5 & 6 \\
\hline J0K0 & 47.92 & 14.68 & - & 5.31 & 23.40 & - \\
J1K0 & 61.84 & 38.42 & 0.47 & - & - & 2.49 \\
J2K0 & 42.17 & 5.57 & - & 32.68 & - & - \\
J3K0 & 19.44 & 22.98 & - & - & - & - \\
J4K0 & 31.37 & 8.86 & 4.95 & 41.48 & - & - \\
J5K0 & 39.65 & 48.36 & - & - & - & - \\
J0K1 & 32.56 & 12.91 & - & 4.63 & 12.60 & - \\
J1K1 & 40.17 & 23.01 & 0.40 & - & - & 0.86 \\
J2K1 & 26.56 & 5.06 & - & 17.40 & - & - \\
J3K1 & 23.28 & 15.44 & - & - & - & - \\
J4K1 & 36.34 & 10.04 & 4.40 & 35.50 & - & - \\
J5K1 & 45.41 & 27.76 & - & - & - & - \\
\hline
\end{tabular}

Note. ${ }^{\mathrm{a}}$ See Figures 1 and 2 for scenarios' description. 
Table 2. Minimum level of significance of the Bartlett's test (\%) among rows of C. pepo in different scenarios created by the exclusion of rows $(\mathrm{K})$ and columns $(\mathrm{J})$, in different experimental unit sizes for the trial carried at the winter-spring season

\begin{tabular}{lllllll}
\hline Scenario $^{\mathrm{a}}$ & \multicolumn{7}{c}{ Size of experimental unit in plants } \\
\cline { 2 - 7 } & 1 & 2 & 3 & 4 & 5 & 6 \\
\hline J0K0 & 2.28 & 18.84 & - & 3.69 & 14.89 & - \\
J1K0 & 13.69 & 25.00 & 10.69 & - & - & 14.68 \\
J2K0 & 5.05 & 13.00 & - & 35.62 & - & - \\
J3K0 & 16.08 & 52.93 & - & - & - & - \\
J4K0 & 1.39 & 3.00 & 76.25 & 33.99 & - & - \\
J5K0 & 2.55 & 7.97 & - & - & - & - \\
J0K1 & 2.95 & 10.69 & - & 1.58 & 5.93 & - \\
J1K1 & 10.52 & 15.89 & 7.04 & - & - & 20.39 \\
J2K1 & 6.21 & 6.16 & - & 19.90 & - & - \\
J3K1 & 11.51 & 32.28 & - & - & - & - \\
J4K1 & 0.51 & 0.86 & 58.36 & 16.69 & - & - \\
J5K1 & 3.31 & 3.43 & - & - & - & - \\
\hline
\end{tabular}

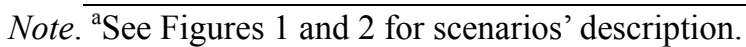

Table 3. Minimum level of significance of the Bartlett's test (\%) among rows of C. annuum in different scenarios created by the exclusion of rows $(\mathrm{K})$ and columns $(\mathrm{J})$, in different experimental unit sizes for the trial carried out in a greenhouses at the autumn-winter season

\begin{tabular}{|c|c|c|c|c|c|c|c|c|c|c|}
\hline \multirow{2}{*}{ Scenario $^{a}$} & \multicolumn{10}{|c|}{ Size of experimental unit in plants } \\
\hline & 1 & 2 & 3 & 4 & 5 & 6 & 7 & 8 & 9 & 10 \\
\hline J0K0 & 0.00 & 0.00 & - & - & - & - & 1.73 & - & - & 11.89 \\
\hline $\mathrm{J} 1 \mathrm{~K} 0$ & 0.00 & 0.00 & - & 2.68 & - & - & - & - & - & - \\
\hline $\mathrm{J} 2 \mathrm{~K} 0$ & 0.00 & 0.00 & 0.03 & - & - & 42.54 & - & - & - & - \\
\hline $\mathrm{J} 3 \mathrm{~K} 0$ & 0.00 & 0.01 & - & 3.71 & - & - & - & 9.21 & - & - \\
\hline $\mathrm{J} 4 \mathrm{~K} 0$ & 0.00 & 0.00 & - & - & - & - & - & - & - & - \\
\hline $\mathrm{J} 5 \mathrm{~K} 0$ & 0.00 & 0.01 & 0.02 & 0.80 & 0.36 & 0.05 & - & - & - & - \\
\hline $\mathrm{J} 6 \mathrm{~K} 0$ & 0.00 & 0.00 & - & - & - & - & - & - & - & - \\
\hline $\mathrm{J} 7 \mathrm{~K} 0$ & 0.00 & 0.01 & - & 1.93 & - & - & 0.63 & 10.48 & - & - \\
\hline $\mathrm{J} 8 \mathrm{~K} 0$ & 0.00 & 0.00 & 0.03 & - & - & 22.38 & - & - & 11.08 & - \\
\hline $\mathrm{J} 9 \mathrm{~K} 0$ & 0.00 & 0.03 & - & 1.60 & - & - & - & - & - & - \\
\hline $\mathrm{J} 10 \mathrm{~K} 0$ & 0.00 & 0.00 & - & - & 0.70 & - & - & - & - & 12.73 \\
\hline $\mathrm{J} 11 \mathrm{~K} 0$ & 0.00 & 0.02 & 0.01 & 1.36 & - & 0.05 & - & 0.67 & - & - \\
\hline $\mathrm{J} 12 \mathrm{~K} 0$ & 0.00 & 0.00 & - & - & - & - & - & - & - & - \\
\hline $\mathrm{J} 13 \mathrm{~K} 0$ & 0.00 & 0.04 & - & 0.38 & - & - & - & - & - & - \\
\hline $\mathrm{J} 14 \mathrm{~K} 0$ & 0.00 & 0.00 & 0.01 & - & - & 34.99 & 0.81 & - & - & - \\
\hline $\mathrm{J} 15 \mathrm{~K} 0$ & 0.00 & 0.05 & - & 2.70 & 1.16 & - & - & 30.23 & - & 13.53 \\
\hline $\mathrm{J} 16 \mathrm{~K} 0$ & 0.00 & 0.00 & - & - & - & - & - & - & - & - \\
\hline $\mathrm{J} 17 \mathrm{~K} 0$ & 0.00 & 0.06 & 0.01 & 0.36 & - & 0.08 & - & - & 19.56 & - \\
\hline J0K1 & 0.00 & 0.00 & - & - & - & - & 0.65 & - & - & 8.84 \\
\hline $\mathrm{J} 1 \mathrm{~K} 1$ & 0.00 & 0.00 & - & 1.16 & - & - & - & - & - & - \\
\hline $\mathrm{J} 2 \mathrm{~K} 1$ & 0.00 & 0.00 & 0.10 & - & - & 41.10 & - & - & - & - \\
\hline J3K1 & 0.00 & 0.00 & - & 3.04 & - & - & - & 6.18 & - & - \\
\hline $\mathrm{J} 4 \mathrm{~K} 1$ & 0.00 & 0.00 & - & - & - & - & - & - & - & - \\
\hline J5K1 & 0.00 & 0.00 & 0.15 & 0.28 & 0.19 & 0.08 & - & - & - & - \\
\hline J6K1 & 0.00 & 0.00 & - & - & - & - & - & - & - & - \\
\hline J7K1 & 0.00 & 0.00 & - & 3.48 & - & - & 0.33 & 7.29 & - & - \\
\hline J8K1 & 0.00 & 0.00 & 0.18 & - & - & 34.49 & - & - & 15.17 & - \\
\hline J9K1 & 0.00 & 0.01 & - & 0.59 & - & - & - & - & - & - \\
\hline $\mathrm{J} 10 \mathrm{~K} 1$ & 0.00 & 0.00 & - & - & 0.41 & - & - & - & - & 6.25 \\
\hline $\mathrm{J} 11 \mathrm{~K} 1$ & 0.00 & 0.01 & 0.14 & 4.66 & - & 0.12 & - & 3.89 & - & - \\
\hline $\mathrm{J} 12 \mathrm{~K} 1$ & 0.00 & 0.00 & - & - & - & - & - & - & - & - \\
\hline $\mathrm{J} 13 \mathrm{~K} 1$ & 0.00 & 0.01 & - & 0.11 & - & - & - & - & - & - \\
\hline $\mathrm{J} 14 \mathrm{~K} 1$ & 0.00 & 0.00 & 0.05 & - & - & 59.63 & 0.46 & - & - & - \\
\hline $\mathrm{J} 15 \mathrm{~K} 1$ & 0.00 & 0.01 & - & 4.29 & 0.63 & - & - & 28.44 & - & 17.56 \\
\hline J16K1 & 0.00 & 0.00 & - & - & - & - & - & - & - & - \\
\hline $\mathrm{J} 17 \mathrm{~K} 1$ & 0.00 & 0.02 & 0.05 & 0.10 & - & 0.08 & - & - & 22.95 & - \\
\hline
\end{tabular}

Note. 'See Figures 1 and 2 for scenarios' description. 
Table 4. Minimum level of significance of the Bartlett's test (\%) among rows of C. annuum in different scenarios created by the exclusion of rows $(\mathrm{K})$ and columns $(\mathrm{J})$, in different experimental unit sizes for the trial carried out in a greenhouses at the spring-summer season

\begin{tabular}{|c|c|c|c|c|c|c|c|c|c|c|}
\hline \multirow{2}{*}{ Scenario $^{\mathrm{a}}$} & \multicolumn{10}{|c|}{ Size of experimental unit in plants } \\
\hline & 1 & 2 & 3 & 4 & 5 & 6 & 7 & 8 & 9 & 10 \\
\hline J0K0 & 0.73 & 0.73 & - & - & - & - & 4.30 & - & - & 23.60 \\
\hline $\mathrm{J} 1 \mathrm{~K} 0$ & 1.39 & 0.34 & - & 0.73 & - & - & - & - & - & - \\
\hline $\mathrm{J} 2 \mathrm{~K} 0$ & 3.10 & 6.58 & 1.28 & - & - & 10.64 & - & - & - & - \\
\hline $\mathrm{J} 3 \mathrm{~K} 0$ & 4.35 & 1.63 & - & 39.40 & - & - & - & 15.11 & - & - \\
\hline $\mathrm{J} 4 \mathrm{~K} 0$ & 3.02 & 7.53 & - & - & - & - & - & - & - & - \\
\hline J5K0 & 52.54 & 34.20 & 19.89 & 8.17 & 86.31 & 42.29 & - & - & - & - \\
\hline J6K0 & 64.26 & 48.88 & - & - & - & - & - & - & - & - \\
\hline $\mathrm{J} 7 \mathrm{~K} 0$ & 65.09 & 39.87 & - & 84.58 & - & - & 28.63 & 48.57 & - & - \\
\hline J8K0 & 73.12 & 47.66 & 13.04 & - & - & 1.40 & - & - & 83.30 & - \\
\hline J9K0 & 59.96 & 38.04 & - & 10.85 & - & - & - & - & - & - \\
\hline $\mathrm{J} 10 \mathrm{~K} 0$ & 52.38 & 25.51 & - & - & 65.43 & - & - & - & - & 62.64 \\
\hline $\mathrm{J} 11 \mathrm{~K} 0$ & 56.22 & 40.88 & 13.20 & 84.73 & - & 61.90 & - & 58.08 & - & - \\
\hline $\mathrm{J} 12 \mathrm{~K} 0$ & 50.09 & 41.10 & - & - & - & - & - & - & - & - \\
\hline $\mathrm{J} 13 \mathrm{~K} 0$ & 59.80 & 23.61 & - & 22.30 & - & - & - & - & - & - \\
\hline $\mathrm{J} 14 \mathrm{~K} 0$ & 72.62 & 33.32 & 18.89 & - & - & 2.80 & 85.62 & - & - & - \\
\hline $\mathrm{J} 15 \mathrm{~K} 0$ & 66.70 & 26.29 & - & 70.68 & 34.88 & - & - & 21.44 & - & 45.09 \\
\hline $\mathrm{J} 16 \mathrm{~K} 0$ & 60.97 & 52.54 & - & - & - & - & - & - & - & - \\
\hline $\mathrm{J} 17 \mathrm{~K} 0$ & 56.44 & 31.00 & 19.03 & 3.83 & - & 75.29 & - & - & 61.02 & - \\
\hline J0K1 & 2.17 & 5.40 & - & - & - & - & 2.82 & - & - & 14.38 \\
\hline $\mathrm{J} 1 \mathrm{~K} 1$ & 3.42 & 1.31 & - & 1.89 & - & - & - & - & - & - \\
\hline $\mathrm{J} 2 \mathrm{~K} 1$ & 5.94 & 25.62 & 11.07 & - & - & 7.26 & - & - & - & - \\
\hline $\mathrm{J} 3 \mathrm{~K} 1$ & 9.78 & 6.08 & - & 35.67 & - & - & - & 7.27 & - & - \\
\hline J4K1 & 5.76 & 31.04 & - & - & - & - & - & - & - & - \\
\hline $\mathrm{J} 5 \mathrm{~K} 1$ & 54.28 & 52.08 & 75.62 & 11.42 & 97.70 & 41.25 & - & - & - & - \\
\hline J6K1 & 64.91 & 83.36 & - & - & - & - & - & - & - & - \\
\hline J7K1 & 61.36 & 57.85 & - & 83.84 & - & - & 21.41 & 74.50 & - & - \\
\hline J8K1 & 70.90 & 74.81 & 61.51 & - & - & 1.93 & - & - & 97.90 & - \\
\hline J9K1 & 51.32 & 54.04 & - & 13.95 & - & - & - & - & - & - \\
\hline $\mathrm{J} 10 \mathrm{~K} 1$ & 42.81 & 55.62 & - & - & 87.78 & - & - & - & - & 61.57 \\
\hline $\mathrm{J} 11 \mathrm{~K} 1$ & 46.33 & 47.31 & 42.18 & 82.45 & - & 60.75 & - & 41.04 & - & - \\
\hline $\mathrm{J} 12 \mathrm{~K} 1$ & 42.96 & 66.86 & - & - & - & - & - & - & - & - \\
\hline $\mathrm{J} 13 \mathrm{~K} 1$ & 46.82 & 23.19 & - & 20.79 & - & - & - & - & - & - \\
\hline $\mathrm{J} 14 \mathrm{~K} 1$ & 58.74 & 48.52 & 33.00 & - & - & 2.40 & 78.69 & - & - & - \\
\hline $\mathrm{J} 15 \mathrm{~K} 1$ & 51.65 & 19.37 & - & 64.52 & 47.44 & - & - & 40.47 & - & 80.77 \\
\hline $\mathrm{J} 16 \mathrm{~K} 1$ & 45.82 & 55.18 & - & - & - & - & - & - & - & - \\
\hline $\mathrm{J} 17 \mathrm{~K} 1$ & 38.96 & 23.20 & 22.24 & 2.41 & - & 70.15 & - & - & 66.10 & - \\
\hline
\end{tabular}

Note. 'See Figures 1 and 2 for scenarios' description.

As far as columns or rows and columns were excluded to create the borders, there were some cases of homogeneity of variances among rows at the trial 2 with $C$. pepo (Table 2). Although there are some scenarios where borders use had provided homogeneity of variances, they seem to reflect aleatory situations, being not possible to establish a behavior pattern of variability as a function of the borders. In the trial 1 , where there were no cases of heterogeneity of variances among rows in the J0K0 scenario, some cases occurred in the scenarios when the borders were considered (Table 1).

In the trial 1 of $C$. annuum, comparing the J0K0 scenario with the others it can be seen that, in most cases, the use of borders had maintained/increased the number of cases of heterogeneity of variances among rows (Table 3 ). For the trial 2, the cases of heterogeneity of variances among rows in the J0K0 scenario ceased to occur in some scenarios when borders were used. However, there were several scenarios in which cases of variance heterogeneity continued occurring (Table 4). 
Regarding the plot size, analyzing the results of the homogeneity tests of variances for the scenario where there was no use of borders ( $\mathrm{J} 0 \mathrm{~K} 0$ scenario), the increase in plot size was effective in reducing the cases of variance heterogeneity among rows in the experiments with C. annuum (Tables 3 and 4).

The only situation where there was significant variability among rows and the increase in plot size did not provide homogenization, it was for the $C$. pepo crop in the trial 2 (Table 2). This result does not contradict the previous one because, although it did not provide homogenization of the variances, the increase of the plot size (number of plants) has provided the maximization on the minimum significant level of the Bartlett's test when 2, 4 and 5 plants were used (Table 2).

In the $\mathrm{J} 0 \mathrm{~K} 0$ scenario, heterogeneity of variance among columns occurred in $25 \%$ of the cases for the $C$. pepo at the trial 2 (Table 5) and $0 \%$ in the trial 1 (Table 6); in $25 \%$ and $75 \%$ of the cases for C. annuumat the trial 2 (Table 7) and trial 1 (Table 8), respectively. Thus, in average, $31.25 \%$ of the trials have presented cases of heterogeneity of variances among columns.

Table 5. Minimum level of significance of the Bartlett's test (\%) among rows of $C$. pepoin different scenarios created by the exclusion of rows $(\mathrm{K})$ and columns $(\mathrm{J})$, in different experimental unit sizes for the trial carried out in a greenhouses at the winter-spring season

\begin{tabular}{lllllll}
\hline Scenario $^{\mathrm{a}}$ & \multicolumn{7}{c}{ Size of experimental unit in plants } \\
\cline { 2 - 7 } & 1 & 2 & 3 & 4 & 5 & 6 \\
\hline J0K0 & 0.43 & 18.95 & - & 16.23 & 52.27 & - \\
J1K0 & 0.45 & 26.08 & 47.44 & - & - & 17.00 \\
J2K0 & 0.25 & 12.14 & - & 79.80 & - & - \\
J3K0 & 0.49 & 13.39 & - & - & - & - \\
J4K0 & 0.18 & 16.34 & 48.57 & 24.22 & - & - \\
J5K0 & 50.34 & 52.90 & - & - & - & - \\
J0K1 & 0.04 & 7.49 & - & 3.13 & 77.29 & - \\
J1K1 & 0.04 & 24.09 & 8.87 & - & - & 0.10 \\
J2K1 & 0.05 & 3.33 & - & 18.92 & - & - \\
J3K1 & 0.10 & 34.32 & - & - & - & - \\
J4K1 & 0.05 & 12.72 & 14.98 & 41.80 & - & - \\
J5K1 & 19.23 & 81.86 & - & - & - & - \\
\hline
\end{tabular}

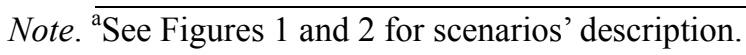

Table 6. Minimum level of significance of the Bartlett's test (\%) among columns of C. pepo in different scenarios created by the exclusion of rows $(\mathrm{K})$ and columns $(\mathrm{J})$, in different experimental unit sizes for the trial carried out in a greenhouses at the summer-autumn season

\begin{tabular}{lllllll}
\hline Scenario $^{a}$ & \multicolumn{7}{c}{ Size of experimental unit in plants } \\
\cline { 2 - 7 } & 1 & 2 & 3 & 4 & 5 & 6 \\
\hline J0K0 & 59.07 & 95.98 & - & 88.97 & 94.66 & - \\
J1K0 & 47.75 & 89.79 & 54.20 & - & - & 43.68 \\
J2K0 & 40.23 & 90.40 & - & 86.47 & - & - \\
J3K0 & 27.15 & 83.65 & - & - & - & - \\
J4K0 & 68.05 & 79.40 & 60.92 & 81.80 & - & - \\
J5K0 & 61.75 & 61.15 & - & - & - & - \\
J0K1 & 41.79 & 81.54 & - & 94.10 & 82.68 & - \\
J1K1 & 35.17 & 0.40 & 88.63 & - & - & 17.05 \\
J2K1 & 34.24 & 87.91 & - & 92.64 & - & - \\
J3K1 & 28.49 & 54.81 & - & - & - & - \\
J4K1 & 49.04 & 69.19 & 77.45 & 99.08 & - & - \\
J5K1 & 36.03 & 33.46 & - & - & - & - \\
\hline
\end{tabular}

Note. 'See Figures 1 and 2 for scenarios' description. 
Table 7. Minimum level of significance of the Bartlett's test (\%) among columns of $C$. annuum in different scenarios created by the exclusion of rows $(\mathrm{K})$ and columns $(\mathrm{J})$, in different experimental unit sizes for the trial carried out at the spring-summer season

\begin{tabular}{|c|c|c|c|c|c|c|c|c|c|c|}
\hline \multirow{2}{*}{ Scenario $^{a}$} & \multicolumn{10}{|c|}{ Size of experimental unit in plants } \\
\hline & 1 & 2 & 3 & 4 & 5 & 6 & 7 & 8 & 9 & 10 \\
\hline J0K0 & 0.42 & 53.49 & - & - & - & - & 37.29 & - & - & 72.61 \\
\hline $\mathrm{J} 1 \mathrm{~K} 0$ & 0.34 & 5.92 & - & 58.40 & - & - & - & - & - & - \\
\hline $\mathrm{J} 2 \mathrm{~K} 0$ & 0.27 & 46.94 & 31.15 & - & - & 44.65 & - & - & - & - \\
\hline $\mathrm{J} 3 \mathrm{~K} 0$ & 0.26 & 5.78 & - & 48.40 & - & - & - & 63.62 & - & - \\
\hline $\mathrm{J} 4 \mathrm{~K} 0$ & 0.43 & 47.36 & - & - & - & - & - & - & - & - \\
\hline $\mathrm{J} 5 \mathrm{~K} 0$ & 52.13 & 65.81 & 74.10 & 86.12 & 86.47 & 75.37 & - & - & - & - \\
\hline J6K0 & 45.79 & 94.34 & - & - & - & - & - & - & - & - \\
\hline $\mathrm{J} 7 \mathrm{~K} 0$ & 44.08 & 61.62 & - & 94.89 & - & - & 56.03 & 84.51 & - & - \\
\hline $\mathrm{J} 8 \mathrm{~K} 0$ & 39.77 & 90.66 & 76.91 & - & - & 87.67 & - & - & 55.54 & - \\
\hline J9K0 & 36.71 & 66.05 & - & 85.75 & - & - & - & - & - & - \\
\hline $\mathrm{J} 10 \mathrm{~K} 0$ & 38.26 & 87.59 & - & - & 77.66 & - & - & - & - & 92.48 \\
\hline J11K0 & 47.99 & 56.54 & 68.28 & 89.72 & - & 66.28 & - & 91.13 & - & - \\
\hline $\mathrm{J} 12 \mathrm{~K} 0$ & 59.24 & 89.72 & - & - & - & - & - & - & - & - \\
\hline $\mathrm{J} 13 \mathrm{~K} 0$ & 74.68 & 71.65 & - & 87.77 & - & - & - & - & - & - \\
\hline $\mathrm{J} 14 \mathrm{~K} 0$ & 84.90 & 87.70 & 63.11 & - & - & 84.58 & 60.35 & - & - & - \\
\hline $\mathrm{J} 15 \mathrm{~K} 0$ & 83.66 & 68.58 & - & 81.19 & 90.27 & - & - & 86.80 & - & 64.48 \\
\hline $\mathrm{J} 16 \mathrm{~K} 0$ & 93.00 & 80.50 & - & - & - & - & - & - & - & - \\
\hline $\mathrm{J} 17 \mathrm{~K} 0$ & 89.63 & 70.20 & 47.28 & 80.15 & - & 47.94 & - & - & 27.63 & - \\
\hline J0K1 & 0.01 & 24.59 & - & - & - & - & 29.00 & - & - & 88.74 \\
\hline $\mathrm{J} 1 \mathrm{~K} 1$ & 0.01 & 2.34 & - & 30.14 & - & - & - & - & - & - \\
\hline $\mathrm{J} 2 \mathrm{~K} 1$ & 0.01 & 18.95 & 30.11 & - & - & 38.01 & - & - & - & - \\
\hline $\mathrm{J} 3 \mathrm{~K} 1$ & 0.02 & 4.60 & - & 41.41 & - & - & - & 62.76 & - & - \\
\hline J4K1 & 0.02 & 27.24 & - & - & - & - & - & - & - & - \\
\hline $\mathrm{J} 5 \mathrm{~K} 1$ & 12.46 & 55.70 & 64.50 & 51.33 & 59.71 & 56.68 & - & - & - & - \\
\hline J6K1 & 9.22 & 77.76 & - & - & - & - & - & - & - & - \\
\hline J7K1 & 7.35 & 69.52 & - & 93.51 & - & - & 33.69 & 63.02 & - & - \\
\hline $\mathrm{J} 8 \mathrm{~K} 1$ & 6.23 & 70.16 & 82.81 & - & - & 61.54 & - & - & 64.04 & - \\
\hline J9K1 & 4.61 & 73.40 & - & 69.85 & - & - & - & - & - & - \\
\hline $\mathrm{J} 10 \mathrm{~K} 1$ & 7.26 & 82.65 & - & - & 50.31 & - & - & - & - & 97.94 \\
\hline $\mathrm{J} 11 \mathrm{~K} 1$ & 6.92 & 63.64 & 73.99 & 86.24 & - & 53.55 & - & 88.89 & - & - \\
\hline $\mathrm{J} 12 \mathrm{~K} 1$ & 8.07 & 81.22 & - & - & - & - & - & - & - & - \\
\hline $\mathrm{J} 13 \mathrm{~K} 1$ & 13.77 & 74.10 & - & 73.05 & - & - & - & - & - & - \\
\hline $\mathrm{J} 14 \mathrm{~K} 1$ & 24.49 & 78.63 & 67.95 & - & - & 59.43 & 47.24 & - & - & - \\
\hline $\mathrm{J} 15 \mathrm{~K} 1$ & 22.23 & 71.66 & - & 85.47 & 68.28 & - & - & 78.04 & - & 71.48 \\
\hline J16K1 & 54.06 & 72.11 & - & - & - & - & - & - & - & - \\
\hline J17K1 & 46.44 & 68.69 & 54.21 & 66.12 & - & 50.17 & - & - & 40.12 & - \\
\hline
\end{tabular}

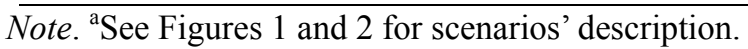


Table 8. Minimum level of significance of the Bartlett's test (\%) among columns of C. annuum in different scenarios created by the exclusion of rows $(\mathrm{K})$ and columns $(\mathrm{J})$, in different experimental unit sizes for the trial carried out at the autumn-winter season

\begin{tabular}{|c|c|c|c|c|c|c|c|c|c|c|}
\hline \multirow{2}{*}{ Scenario $^{\mathrm{a}}$} & \multicolumn{10}{|c|}{ Size of experimental unit in plants } \\
\hline & 1 & 2 & 3 & 4 & 5 & 6 & 7 & 8 & 9 & 10 \\
\hline J0K0 & 0.00 & 0.00 & - & - & - & - & 0.32 & - & - & 7.55 \\
\hline $\mathrm{J} 1 \mathrm{~K} 0$ & 0.00 & 0.00 & - & 0.00 & - & - & - & - & - & - \\
\hline $\mathrm{J} 2 \mathrm{~K} 0$ & 0.00 & 0.00 & 0.00 & - & - & 2.22 & - & - & - & - \\
\hline $\mathrm{J} 3 \mathrm{~K} 0$ & 0.00 & 0.00 & - & 9.86 & - & - & - & 18.76 & - & - \\
\hline $\mathrm{J} 4 \mathrm{~K} 0$ & 0.00 & 0.11 & - & - & - & - & - & - & - & - \\
\hline $\mathrm{J} 5 \mathrm{~K} 0$ & 0.00 & 0.00 & 0.00 & 0.03 & 0.03 & 7.68 & - & - & - & - \\
\hline J6K0 & 0.00 & 0.05 & - & - & - & - & - & - & - & - \\
\hline $\mathrm{J} 7 \mathrm{~K} 0$ & 0.00 & 0.00 & - & 5.85 & - & - & 0.21 & 17.13 & - & - \\
\hline J8K0 & 0.00 & 0.02 & 0.01 & - & - & 3.02 & - & - & 73.23 & - \\
\hline J9K0 & 0.00 & 0.00 & - & 0.03 & - & - & - & - & - & - \\
\hline $\mathrm{J} 10 \mathrm{~K} 0$ & 0.00 & 0.01 & - & - & 0.02 & - & - & - & - & 28.96 \\
\hline $\mathrm{J} 11 \mathrm{~K} 0$ & 0.00 & 0.00 & 0.00 & 4.43 & - & 2.99 & - & 12.67 & - & - \\
\hline $\mathrm{J} 12 \mathrm{~K} 0$ & 0.00 & 0.01 & - & - & - & - & - & - & - & - \\
\hline $\mathrm{J} 13 \mathrm{~K} 0$ & 0.00 & 0.00 & - & 0.11 & - & - & - & - & - & - \\
\hline $\mathrm{J} 14 \mathrm{~K} 0$ & 0.00 & 0.02 & 0.01 & - & - & 6.09 & 0.12 & - & - & - \\
\hline $\mathrm{J} 15 \mathrm{~K} 0$ & 0.00 & 0.00 & - & 6.14 & 0.01 & - & - & 15.41 & - & 52.49 \\
\hline $\mathrm{J} 16 \mathrm{~K} 0$ & 0.00 & 0.01 & - & - & - & - & - & - & - & - \\
\hline $\mathrm{J} 17 \mathrm{~K} 0$ & 0.00 & 0.01 & 0.01 & 0.23 & - & 2.18 & - & - & 54.02 & - \\
\hline J0K1 & 0.00 & 0.00 & - & - & - & - & 0.12 & - & - & 9.00 \\
\hline $\mathrm{J} 1 \mathrm{~K} 1$ & 0.00 & 0.00 & - & 0.00 & - & - & - & - & - & - \\
\hline $\mathrm{J} 2 \mathrm{~K} 1$ & 0.00 & 0.00 & 0.00 & - & - & 2.24 & - & - & - & - \\
\hline $\mathrm{J} 3 \mathrm{~K} 1$ & 0.00 & 0.00 & - & 5.88 & - & - & - & 11.43 & - & - \\
\hline $\mathrm{J} 4 \mathrm{~K} 1$ & 0.00 & 0.00 & - & - & - & - & - & - & - & - \\
\hline J5K1 & 0.00 & 0.00 & 0.00 & 0.00 & 0.02 & 0.14 & - & - & - & - \\
\hline J6K1 & 0.00 & 0.00 & - & - & - & - & - & - & - & - \\
\hline $\mathrm{J} 7 \mathrm{~K} 1$ & 0.00 & 0.00 & - & 5.06 & - & - & 0.04 & 2.75 & - & - \\
\hline J8K1 & 0.00 & 0.00 & 0.00 & - & - & 6.44 & - & - & 27.87 & - \\
\hline J9K1 & 0.00 & 0.00 & - & 0.00 & - & - & - & - & - & - \\
\hline $\mathrm{J} 10 \mathrm{~K} 1$ & 0.00 & 0.00 & - & - & 0.02 & - & - & - & - & 5.70 \\
\hline $\mathrm{J} 11 \mathrm{~K} 1$ & 0.00 & 0.00 & 0.00 & 2.65 & - & 0.04 & - & 5.29 & - & - \\
\hline $\mathrm{J} 12 \mathrm{~K} 1$ & 0.00 & 0.00 & - & - & - & - & - & - & - & - \\
\hline $\mathrm{J} 13 \mathrm{~K} 1$ & 0.00 & 0.00 & - & 0.01 & - & - & - & - & - & - \\
\hline $\mathrm{J} 14 \mathrm{~K} 1$ & 0.00 & 0.00 & 0.00 & - & - & 9.48 & 0.01 & - & - & - \\
\hline $\mathrm{J} 15 \mathrm{~K} 1$ & 0.00 & 0.00 & - & 3.13 & 0.01 & - & - & 1.57 & - & 5.96 \\
\hline $\mathrm{J} 16 \mathrm{~K} 1$ & 0.00 & 0.00 & - & - & - & - & - & - & - & - \\
\hline $\mathrm{J} 17 \mathrm{~K} 1$ & 0.00 & 0.00 & 0.00 & 0.01 & - & 0.02 & - & - & 13.07 & - \\
\hline
\end{tabular}

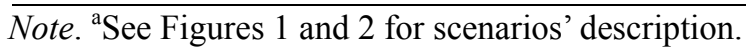

There was no case of heterogeneity of variances among columns in the J5K0 scenario for the $C$. pepoat the trial 2 (Table 5). This result suggests that the use of a five-plant border could be used to homogenize the variances among columns; however, considering the absence of a pattern of reduction of cases of heterogeneity in the other exclusions, this recommendation may be biased. This is confirmed by observing results for this same crop at the trial 1. In this case, the variances that were homogeneous in the J0K0 scenario became heterogeneous it in the J1K1 scenario (Table 6).

In the second trial with $C$. annuum, scenarios with borders consisting of up to four columns (plants) have maintained the number of cases of heterogeneity variances obtained in the J0K0 scenario; on the other hand, the use of borders consisting of 5 to 17 columns, have reduced the cases of variance heterogeneity to zero (Table 7). In the J0K1 scenario, where the border was composed of rows, the proportion of heterogeneity remained, however in the scenarios where the border was composed of rows and columns (scenarios J1K1 to J17K1) there were some cases with homogeneity among columns (Table 7). 
Although there were cases where the use of borders made the variances homogeneous among columns, there were cases where the use of borders maintained or increased the proportion of cases of variance heterogeneity. Thus, it is not possible to establish a cause and effect relationship between the use of borders made up of rows and columns, with cases of heterogeneity/homogeneity of variance among columns.

The results obtained in the first trial of $C$. annuum showed that the scenarios that enabled the decrease of the cases of heterogeneity in the second trial (Table 7), increased the proportion of that cases at the first trial (Table 8).

Similar to the variability among rows, the increase in plot size allowed the homogenization of variances between columns. This was verified for C. pepo at the second trial (Table 5) and for C. annuum at the second trial (Table 7) and first trial (Table 8). For the J0K0 scenario, homogenization of variances between columns was obtained with the use of a plot size greater than or equal to two plants for C. pepo and greater than or equal to ten plants for $C$. annuum

At the second trial with $C$. pepo, in the J0K0 scenario, the coefficient of variation for the plot of one plant was $24.94 \%$ (Table 9), while in first trial it was 57.77\% (Table 10). In the second trial in the J5K0 and J5K1 scenarios, a reduction on the value of the variance and coefficient of variation was obtained in relation to the situation where no exclusions were made. This peculiarity had occurred in all tested plot sizes (Table 9). At trial 2, however, the exclusion of this same number of columns increased the variance and coefficient of variation (Table 10).For C. annuum, a coefficient of variation of $44.21 \%$ was obtained at the trial 2 (Table 11) and $39.92 \%$ at trial 1 (Table 12).

In both trials for $C$. annuum (Tables 11, 12, 13, and 14) no benefits were seen in terms of reduction in coefficient of variation or variance when rows or columns were excluded.

Table 9. Variance $\left(\mathrm{s}^{2}\right.$ in $\left.\mathrm{g}^{2} 10^{4}\right)$ and coefficient of variation $(\mathrm{CV}$, in percentage) for the fresh mass of fruits of $C$. pepo in different scenarios created by the exclusion of rows $(\mathrm{K})$ and columns $(\mathrm{J})$, in different experimental unit sizes for the trial carried out at the winter-spring season

\begin{tabular}{|c|c|c|c|c|c|c|c|}
\hline \multirow{2}{*}{ Scenario $^{\mathrm{a}}$} & & \multicolumn{6}{|c|}{ Size of experimental unit in plants } \\
\hline & & 1 & 2 & 3 & 4 & 5 & 6 \\
\hline \multirow[t]{2}{*}{ J0K0 } & $\mathrm{s}^{2}$ & 21.79 & 43.72 & - & 90.16 & 120.48 & - \\
\hline & $\mathrm{CV}$ & 24.94 & 17.65 & - & 12.74 & 11.95 & - \\
\hline \multirow[t]{2}{*}{$\mathrm{J} 1 \mathrm{~K} 0$} & $\mathrm{~s}^{2}$ & 20.67 & 38.96 & 62.54 & - & - & 148.55 \\
\hline & $\mathrm{CV}$ & 24.19 & 16.75 & 14.40 & - & - & 10.93 \\
\hline \multirow[t]{2}{*}{$\mathrm{J} 2 \mathrm{~K} 0$} & $s^{2}$ & 20.54 & 44.55 & - & 79.76 & - & - \\
\hline & $\mathrm{CV}$ & 23.83 & 17.64 & - & 12.26 & - & - \\
\hline \multirow[t]{2}{*}{$\mathrm{J} 3 \mathrm{~K} 0$} & $\mathrm{~s}^{2}$ & 19.74 & 39.75 & - & - & - & - \\
\hline & $\mathrm{CV}$ & 22.89 & 16.30 & - & - & - & - \\
\hline \multirow[t]{2}{*}{$\mathrm{J} 4 \mathrm{~K} 0$} & $\mathrm{~s}^{2}$ & 19.44 & 37.39 & 47.74 & 56.55 & - & - \\
\hline & $\mathrm{CV}$ & 23.01 & 16.36 & 12.61 & 10.20 & - & - \\
\hline \multirow[t]{2}{*}{$\mathrm{J} 5 \mathrm{~K} 0$} & $s^{2}$ & 11.26 & 25.37 & - & - & - & - \\
\hline & $\mathrm{CV}$ & 17.92 & 13.42 & - & - & - & - \\
\hline \multirow[t]{2}{*}{ J0K1 } & $\mathrm{s}^{2}$ & 23.22 & 41.45 & - & 76.45 & 77.10 & - \\
\hline & $\mathrm{CV}$ & 24.66 & 16.48 & - & 10.97 & 9.58 & - \\
\hline \multirow[t]{2}{*}{$\mathrm{J} 1 \mathrm{~K} 1$} & $\mathrm{~s}^{2}$ & 21.13 & 33.71 & 49.07 & - & - & 100.02 \\
\hline & $\mathrm{CV}$ & 23.17 & 15.01 & 11.97 & - & - & 7.85 \\
\hline \multirow[t]{2}{*}{$\mathrm{J} 2 \mathrm{~K} 1$} & $\mathrm{~s}^{2}$ & 22.35 & 43.92 & - & 48.75 & - & - \\
\hline & $\mathrm{CV}$ & 23.72 & 16.56 & - & 9.04 & - & - \\
\hline \multirow[t]{2}{*}{$\mathrm{J} 3 \mathrm{~K} 1$} & $\mathrm{~s}^{2}$ & 20.64 & 36.82 & - & - & - & - \\
\hline & $\mathrm{CV}$ & 22.11 & 15.35 & - & - & - & - \\
\hline \multirow[t]{2}{*}{$\mathrm{J} 4 \mathrm{~K} 1$} & $\mathrm{~s}^{2}$ & 20.66 & 32.03 & 39.71 & 41.98 & - & - \\
\hline & $\mathrm{CV}$ & 22.45 & 14.73 & 10.95 & 8.77 & - & - \\
\hline \multirow[t]{2}{*}{$\mathrm{J} 5 \mathrm{~K} 1$} & $\mathrm{~s}^{2}$ & 10.30 & 24.11 & - & - & - & - \\
\hline & $\mathrm{CV}$ & 16.75 & 13.11 & - & - & - & - \\
\hline
\end{tabular}

Note. 'See Figures 1 and 2 for scenarios' description. 
Table 10. Variance $\left(\mathrm{s}^{2}\right.$ in $\left.\mathrm{g}^{2} 10^{4}\right)$ and coefficient of variation $(\mathrm{CV}$, in percentage) for the fresh mass of fruits of $C$. pepo in different scenarios created by the exclusion of rows (K) and columns (J), in different experimental unit sizes for the trial carried out in a greenhouses at the summer-autumn season

\begin{tabular}{|c|c|c|c|c|c|c|c|}
\hline \multirow{2}{*}{ Scenario $^{\mathrm{a}}$} & & \multicolumn{6}{|c|}{ Size of experimental unit in plants } \\
\hline & & 1 & 2 & 3 & 4 & 5 & 6 \\
\hline \multirow[t]{2}{*}{ J0K0 } & $\mathrm{s}^{2}$ & 3.97 & 6.73 & - & 14.68 & 25.04 & - \\
\hline & $\mathrm{CV}$ & 57.77 & 37.22 & - & 27.18 & 28.73 & - \\
\hline \multirow[t]{2}{*}{$\mathrm{J} 1 \mathrm{~K} 0$} & $s^{2}$ & 4.05 & 8.35 & 11.83 & - & - & 28.13 \\
\hline & $\mathrm{CV}$ & 58.67 & 41.67 & 32.69 & - & - & 24.78 \\
\hline \multirow[t]{2}{*}{$\mathrm{J} 2 \mathrm{~K} 0$} & $s^{2}$ & 4.11 & 6.84 & - & 16.14 & - & - \\
\hline & $\mathrm{CV}$ & 59.75 & 38.13 & - & 29.12 & - & - \\
\hline \multirow[t]{2}{*}{$\mathrm{J} 3 \mathrm{~K} 0$} & $s^{2}$ & 4.16 & 7.75 & - & - & - & - \\
\hline & $\mathrm{CV}$ & 58.97 & 40.02 & - & - & - & - \\
\hline \multirow[t]{2}{*}{$\mathrm{J} 4 \mathrm{~K} 0$} & $s^{2}$ & 4.55 & 6.58 & 9.48 & 12.68 & - & - \\
\hline & $\mathrm{CV}$ & 62.53 & 36.55 & 29.38 & 25.17 & - & - \\
\hline \multirow[t]{2}{*}{$\mathrm{J} 5 \mathrm{~K} 0$} & $s^{2}$ & 4.55 & 7.46 & - & - & - & - \\
\hline & $\mathrm{CV}$ & 62.98 & 39.58 & - & - & - & - \\
\hline \multirow[t]{2}{*}{ J0K1 } & $s^{2}$ & 4.22 & 7.18 & - & 13.83 & 26.45 & - \\
\hline & $\mathrm{CV}$ & 59.11 & 37.97 & - & 26.38 & 29.33 & - \\
\hline \multirow[t]{2}{*}{$\mathrm{J} 1 \mathrm{~K} 1$} & $s^{2}$ & 4.37 & 8.25 & 10.94 & - & - & 28.86 \\
\hline & $\mathrm{CV}$ & 60.91 & 41.19 & 31.60 & - & - & 23.93 \\
\hline \multirow[t]{2}{*}{$\mathrm{J} 2 \mathrm{~K} 1$} & $\mathrm{~s}^{2}$ & 4.53 & 7.37 & - & 18.80 & - & - \\
\hline & $\mathrm{CV}$ & 63.12 & 39.78 & - & 31.90 & - & - \\
\hline \multirow[t]{2}{*}{$\mathrm{J} 3 \mathrm{~K} 1$} & $s^{2}$ & 4.76 & 8.76 & - & - & - & - \\
\hline & $\mathrm{CV}$ & 64.32 & 42.75 & - & - & - & - \\
\hline \multirow[t]{2}{*}{ J4K1 } & $s^{2}$ & 5.26 & 7.32 & 9.73 & 12.17 & - & - \\
\hline & $\mathrm{CV}$ & 69.18 & 39.41 & 30.52 & 25.81 & - & - \\
\hline \multirow[t]{2}{*}{$\mathrm{J} 5 \mathrm{~K} 1$} & $\mathrm{~s}^{2}$ & 5.28 & 7.89 & - & - & - & - \\
\hline & $\mathrm{CV}$ & 71.10 & 42.09 & - & - & - & - \\
\hline
\end{tabular}

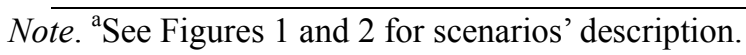


Table 11. Variance $\left(\mathrm{s}^{2}\right.$ in $\left.\mathrm{g}^{2} 10^{4}\right)$ and coefficient of variation $(\mathrm{CV}$, in percentage) for the fresh mass of fruits of $C$. annuum in different scenarios created by the exclusion of columns $(\mathrm{J})$, in different experimental unit sizes for the trial carried out at the spring-summer season

\begin{tabular}{|c|c|c|c|c|c|c|c|c|c|c|c|}
\hline \multirow{2}{*}{ Scenario $^{a}$} & & \multicolumn{10}{|c|}{ Size of experimental unit in plants } \\
\hline & & 1 & 2 & 3 & 4 & 5 & 6 & 7 & 8 & 9 & 10 \\
\hline \multirow[t]{2}{*}{$\mathrm{J} 0 \mathrm{~K} 0$} & $\mathrm{~s}^{2}$ & 3.29 & 6.31 & - & - & - & - & 23.83 & - & - & 39.41 \\
\hline & $\mathrm{CV}$ & 44.21 & 31.00 & - & - & - & - & 17.12 & - & - & 15.53 \\
\hline \multirow[t]{2}{*}{$\mathrm{J} 1 \mathrm{~K} 0$} & $s^{2}$ & 3.32 & 6.71 & - & 14.74 & - & - & - & - & - & - \\
\hline & $\mathrm{CV}$ & 44.09 & 31.32 & - & 23.54 & - & - & - & - & - & - \\
\hline \multirow[t]{2}{*}{$\mathrm{J} 2 \mathrm{~K} 0$} & $s^{2}$ & 3.34 & 6.36 & 11.36 & - & - & 22.61 & - & - & - & - \\
\hline & $\mathrm{CV}$ & 44.24 & 30.88 & 27.33 & - & - & 19.34 & - & - & - & - \\
\hline \multirow[t]{2}{*}{$\mathrm{J} 3 \mathrm{~K} 0$} & $s^{2}$ & 3.32 & 6.66 & - & 13.53 & - & - & - & 28.10 & - & - \\
\hline & $\mathrm{CV}$ & 43.97 & 31.12 & - & 22.39 & - & - & - & 16.26 & - & - \\
\hline \multirow[t]{2}{*}{$\mathrm{J} 4 \mathrm{~K} 0$} & $s^{2}$ & 3.36 & 6.27 & - & - & - & - & - & - & - & - \\
\hline & $\mathrm{CV}$ & 44.33 & 30.67 & - & - & - & - & - & - & - & - \\
\hline \multirow[t]{2}{*}{$\mathrm{J} 5 \mathrm{~K} 0$} & $s^{2}$ & 3.07 & 6.08 & 10.13 & 13.11 & 15.26 & 19.46 & - & - & - & - \\
\hline & $\mathrm{CV}$ & 43.14 & 30.19 & 25.93 & 22.26 & 19.16 & 18.10 & - & - & - & - \\
\hline \multirow[t]{2}{*}{ J6K0 } & $s^{2}$ & 3.08 & 5.77 & - & - & - & - & - & - & - & - \\
\hline & $\mathrm{CV}$ & 43.26 & 29.78 & - & - & - & - & - & - & - & - \\
\hline \multirow[t]{2}{*}{$\mathrm{J} 7 \mathrm{~K} 0$} & $s^{2}$ & 3.10 & 6.18 & - & 12.09 & - & - & 20.22 & 26.34 & - & - \\
\hline & $\mathrm{CV}$ & 43.46 & 30.50 & - & 21.53 & - & - & 15.78 & 15.86 & - & - \\
\hline \multirow[t]{2}{*}{ J8K0 } & $s^{2}$ & 3.10 & 5.71 & 10.17 & - & - & 18.94 & - & - & 30.87 & - \\
\hline & $\mathrm{CV}$ & 43.55 & 29.66 & 26.13 & - & - & 17.95 & - & - & 15.17 & - \\
\hline \multirow[t]{2}{*}{ J9K0 } & $s^{2}$ & 3.14 & 6.39 & - & 13.58 & - & - & - & - & - & - \\
\hline & $\mathrm{CV}$ & 43.88 & 31.15 & - & 22.80 & - & - & - & - & - & - \\
\hline \multirow[t]{2}{*}{$\mathrm{J} 10 \mathrm{~K} 0$} & $s^{2}$ & 3.14 & 5.75 & - & - & 15.69 & - & - & - & - & 36.08 \\
\hline & $\mathrm{CV}$ & 43.57 & 29.69 & - & - & 19.42 & - & - & - & - & 14.89 \\
\hline \multirow[t]{2}{*}{$\mathrm{J} 11 \mathrm{~K} 0$} & $\mathrm{~s}^{2}$ & 3.13 & 6.86 & 10.45 & 12.42 & - & 19.52 & - & 24.16 & - & - \\
\hline & $\mathrm{CV}$ & 43.77 & 31.75 & 26.45 & 21.81 & - & 18.21 & - & 15.25 & - & - \\
\hline \multirow[t]{2}{*}{$\mathrm{J} 12 \mathrm{~K} 0$} & $\mathrm{~s}^{2}$ & 3.18 & 5.83 & - & - & - & - & - & - & - & - \\
\hline & $\mathrm{CV}$ & 43.98 & 29.93 & - & - & - & - & - & - & - & - \\
\hline \multirow[t]{2}{*}{$\mathrm{J} 13 \mathrm{~K} 0$} & $s^{2}$ & 3.11 & 6.41 & - & 13.19 & - & - & - & - & - & - \\
\hline & $\mathrm{CV}$ & 43.65 & 31.00 & - & 22.35 & - & - & - & - & - & - \\
\hline \multirow[t]{2}{*}{$\mathrm{J} 14 \mathrm{~K} 0$} & $s^{2}$ & 3.00 & 5.64 & 10.50 & - & - & 18.42 & 18.32 & - & - & - \\
\hline & $\mathrm{CV}$ & 42.47 & 29.15 & 26.10 & - & - & 17.46 & 14.89 & - & - & - \\
\hline \multirow[t]{2}{*}{$\mathrm{J} 15 \mathrm{~K} 0$} & $s^{2}$ & 3.01 & 6.32 & - & 12.29 & 15.40 & - & - & 26.67 & - & 30.38 \\
\hline & $\mathrm{CV}$ & 42.45 & 30.37 & - & 21.26 & 19.09 & - & - & 15.79 & - & 13.40 \\
\hline \multirow[t]{2}{*}{$\mathrm{J} 16 \mathrm{~K} 0$} & $s^{2}$ & 2.95 & 5.59 & - & - & - & - & - & - & - & - \\
\hline & $\mathrm{CV}$ & 42.32 & 29.00 & - & - & - & - & - & - & - & - \\
\hline \multirow[t]{2}{*}{$\mathrm{J} 17 \mathrm{~K} 0$} & $s^{2}$ & 2.96 & 6.05 & 10.37 & 12.85 & - & 18.33 & - & - & 29.66 & - \\
\hline & $\mathrm{CV}$ & 42.61 & 30.00 & 25.94 & 21.96 & - & 17.43 & - & - & 14.58 & - \\
\hline
\end{tabular}

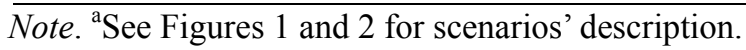


Table 12. Variance $\left(\mathrm{s}^{2}\right.$ in $\left.\mathrm{g}^{2} 10^{4}\right)$ and coefficient of variation (CV, in percentage) for the fresh mass of fruits of $C$. annuum in different scenarios created by the exclusion columns $(\mathrm{J})$, in different experimental unit sizes for the trial carried out at the autumn-winter season

\begin{tabular}{|c|c|c|c|c|c|c|c|c|c|c|c|}
\hline \multirow{2}{*}{ Scenario $^{a}$} & & \multicolumn{10}{|c|}{ Size of experimental unit in plants } \\
\hline & & 1 & 2 & 3 & 4 & 5 & 6 & 7 & 8 & 9 & 10 \\
\hline \multirow[t]{2}{*}{ J0K0 } & $\mathrm{s}^{2}$ & 2.30 & 5.01 & - & - & - & - & 25.93 & - & - & 38.87 \\
\hline & $\mathrm{CV}$ & 39.92 & 29.80 & - & - & - & - & 19.76 & - & - & 17.34 \\
\hline \multirow[t]{2}{*}{$\mathrm{J} 1 \mathrm{~K} 0$} & $s^{2}$ & 2.29 & 5.09 & - & 11.89 & - & - & - & - & - & - \\
\hline & $\mathrm{CV}$ & 39.72 & 29.79 & - & 23.00 & - & - & - & - & - & - \\
\hline \multirow[t]{2}{*}{$\mathrm{J} 2 \mathrm{~K} 0$} & $s^{2}$ & 2.06 & 4.51 & 7.36 & - & - & 18.22 & - & - & - & - \\
\hline & $\mathrm{CV}$ & 39.02 & 28.93 & 24.50 & - & - & 19.71 & - & - & - & - \\
\hline \multirow[t]{2}{*}{$\mathrm{J} 3 \mathrm{~K} 0$} & $\mathrm{~s}^{2}$ & 2.03 & 4.40 & - & 9.49 & - & - & - & 24.65 & - & - \\
\hline & $\mathrm{CV}$ & 38.68 & 28.38 & - & 21.65 & - & - & - & 17.52 & - & - \\
\hline \multirow[t]{2}{*}{$\mathrm{J} 4 \mathrm{~K} 0$} & $s^{2}$ & 2.05 & 4.42 & - & - & - & - & - & - & - & - \\
\hline & $\mathrm{CV}$ & 38.90 & 28.80 & - & - & - & - & - & - & - & - \\
\hline \multirow[t]{2}{*}{ J5K0 } & $s^{2}$ & 2.04 & 4.39 & 7.14 & $1-$ & 13.18 & 16.28 & - & - & - & - \\
\hline & $\mathrm{CV}$ & 38.72 & 28.27 & 24.07 & 21.40 & 19.52 & 18.78 & - & - & - & - \\
\hline \multirow[t]{2}{*}{ J6K0 } & $s^{2}$ & 2.04 & 4.45 & - & - & - & - & - & - & - & - \\
\hline & $\mathrm{CV}$ & 38.75 & 28.88 & - & - & - & - & - & - & - & - \\
\hline \multirow[t]{2}{*}{ J7K0 } & $s^{2}$ & 2.08 & 4.53 & - & 9.29 & - & - & 22.70 & 21.84 & - & - \\
\hline & $\mathrm{CV}$ & 39.14 & 28.80 & - & 21.50 & - & - & 18.57 & 16.56 & - & - \\
\hline \multirow[t]{2}{*}{ J8K0 } & $s^{2}$ & 2.10 & 4.52 & 7.44 & - & - & 17.08 & - & - & 29.95 & - \\
\hline & $\mathrm{CV}$ & 39.18 & 29.00 & 24.59 & - & - & 19.15 & - & - & 17.58 & - \\
\hline \multirow[t]{2}{*}{ J9K0 } & $s^{2}$ & 2.12 & 4.58 & - & 10.46 & - & - & - & - & - & - \\
\hline & $\mathrm{CV}$ & 39.15 & 28.55 & - & 21.78 & - & - & - & - & - & - \\
\hline \multirow[t]{2}{*}{ J10K0 } & $s^{2}$ & 2.17 & 4.57 & - & - & 13.57 & - & - & - & - & 26.60 \\
\hline & $\mathrm{CV}$ & 39.60 & 28.97 & - & - & 19.62 & - & - & - & - & 14.79 \\
\hline \multirow[t]{2}{*}{ J11K0 } & $s^{2}$ & 2.14 & 4.57 & 7.24 & 8.63 & - & 16.10 & - & 21.58 & - & - \\
\hline & $\mathrm{CV}$ & 39.11 & 28.30 & 23.91 & 20.42 & - & 18.41 & - & 16.29 & - & - \\
\hline \multirow[t]{2}{*}{$\mathrm{J} 12 \mathrm{~K} 0$} & $\mathrm{~s}^{2}$ & 2.09 & 4.32 & - & - & - & - & - & - & - & - \\
\hline & $\mathrm{CV}$ & 38.73 & 28.19 & - & - & - & - & - & - & - & - \\
\hline \multirow[t]{2}{*}{$\mathrm{J} 13 \mathrm{~K} 0$} & $s^{2}$ & 1.90 & 4.19 & - & 9.12 & - & - & - & - & - & - \\
\hline & $\mathrm{CV}$ & 37.88 & 27.76 & - & 20.74 & - & - & - & - & - & - \\
\hline \multirow[t]{2}{*}{ J14K0 } & $s^{2}$ & 1.92 & 4.26 & 6.97 & - & - & 14.42 & 19.59 & - & - & - \\
\hline & $\mathrm{CV}$ & 37.83 & 28.19 & 23.75 & - & - & 17.93 & 17.08 & - & - & - \\
\hline \multirow[t]{2}{*}{$\mathrm{J} 15 \mathrm{~K} 0$} & $s^{2}$ & 1.94 & 4.41 & - & 8.70 & 13.46 & - & - & 18.09 & - & 30.60 \\
\hline & $\mathrm{CV}$ & 37.99 & 28.48 & - & 20.84 & 19.61 & - & - & 15.21 & - & 16.15 \\
\hline \multirow[t]{2}{*}{$\mathrm{J} 16 \mathrm{~K} 0$} & $s^{2}$ & 1.95 & 4.37 & - & - & - & - & - & - & - & - \\
\hline & $\mathrm{CV}$ & 38.05 & 28.51 & - & - & - & - & - & - & - & - \\
\hline \multirow[t]{2}{*}{$\mathrm{J} 17 \mathrm{~K} 0$} & $\mathrm{~s}^{2}$ & 1.98 & 4.65 & 7.50 & 10.28 & - & 17.82 & - & - & 29.13 & - \\
\hline & $\mathrm{CV}$ & 38.16 & 29.33 & 24.59 & 22.15 & - & 19.55 & - & - & 17.58 & - \\
\hline
\end{tabular}

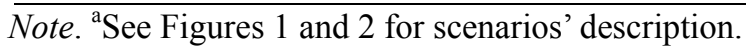


Table 13. Variance $\left(\mathrm{s}^{2}\right.$ in $\left.\mathrm{g}^{2} 10^{4}\right)$ and coefficient of variation $(\mathrm{CV}$, in percentage) for the fresh mass of fruits of $C$. annuum in different scenarios created by the exclusion of rows $(\mathrm{K})$ and columns $(\mathrm{J})$, in different experimental unit sizes for the trial carried out at the spring-summer season

\begin{tabular}{|c|c|c|c|c|c|c|c|c|c|c|c|}
\hline \multirow{2}{*}{ Scenario $^{a}$} & & \multicolumn{10}{|c|}{ Size of experimental unit in plants } \\
\hline & & 1 & 2 & 3 & 4 & 5 & 6 & 7 & 8 & 9 & 10 \\
\hline \multirow[t]{2}{*}{ J0K1 } & $\mathrm{s}^{2}$ & 3.45 & 6.81 & - & - & - & - & 24.76 & - & - & 37.58 \\
\hline & $\mathrm{CV}$ & 44.09 & 31.48 & - & - & - & - & 17.07 & - & - & 15.04 \\
\hline \multirow[t]{2}{*}{$\mathrm{J} 1 \mathrm{~K} 1$} & $s^{2}$ & 3.48 & 7.23 & - & 15.89 & - & - & - & - & - & - \\
\hline & $\mathrm{CV}$ & 43.87 & 31.79 & - & 23.89 & - & - & - & - & - & - \\
\hline \multirow[t]{2}{*}{$\mathrm{J} 2 \mathrm{~K} 1$} & $s^{2}$ & 3.49 & 6.84 & 12.46 & - & - & 23.44 & - & - & - & - \\
\hline & $\mathrm{CV}$ & 43.88 & 31.25 & 28.13 & - & - & 19.30 & - & - & - & - \\
\hline \multirow[t]{2}{*}{$\mathrm{J} 3 \mathrm{~K} 1$} & $s^{2}$ & 3.47 & 7.18 & - & 13.55 & - & - & - & 28.74 & - & - \\
\hline & $\mathrm{CV}$ & 43.79 & 31.72 & - & 21.95 & - & - & - & 16.19 & - & - \\
\hline \multirow[t]{2}{*}{$\mathrm{J} 4 \mathrm{~K} 1$} & $\mathrm{~s}^{2}$ & 3.51 & 6.78 & - & - & - & - & - & - & - & - \\
\hline & $\mathrm{CV}$ & 44.14 & 31.26 & - & - & - & - & - & - & - & - \\
\hline \multirow[t]{2}{*}{$\mathrm{J} 5 \mathrm{~K} 1$} & $s^{2}$ & 3.12 & 6.40 & 10.96 & 13.84 & 14.45 & 19.46 & - & - & - & - \\
\hline & $\mathrm{CV}$ & 42.57 & 30.53 & 26.59 & 22.39 & 18.31 & 17.74 & - & - & - & - \\
\hline \multirow[t]{2}{*}{$\mathrm{J} 6 \mathrm{~K} 1$} & $\mathrm{~s}^{2}$ & 3.12 & 6.10 & - & - & - & - & - & - & - & - \\
\hline & $\mathrm{CV}$ & 42.70 & 30.18 & - & - & - & - & - & - & - & - \\
\hline \multirow[t]{2}{*}{$\mathrm{J} 7 \mathrm{~K} 1$} & $s^{2}$ & 3.14 & 6.56 & - & 11.60 & - & - & 20.84 & 23.02 & - & - \\
\hline & $\mathrm{CV}$ & 42.86 & 31.13 & - & 20.92 & - & - & 15.69 & 14.53 & - & - \\
\hline \multirow[t]{2}{*}{ J8K1 } & $s^{2}$ & 3.16 & 6.00 & 11.01 & - & - & 19.43 & - & - & 32.21 & - \\
\hline & $\mathrm{CV}$ & 42.95 & 29.95 & 26.94 & - & - & 17.83 & - & - & 15.39 & - \\
\hline \multirow[t]{2}{*}{ J9K1 } & $s^{2}$ & 3.19 & 6.78 & - & 14.38 & - & - & - & - & - & - \\
\hline & $\mathrm{CV}$ & 43.24 & 31.77 & - & 23.10 & - & - & - & - & - & - \\
\hline \multirow[t]{2}{*}{$\mathrm{J} 10 \mathrm{~K} 1$} & $\mathrm{~s}^{2}$ & 3.20 & 6.11 & - & - & 14.61 & - & - & - & - & 32.56 \\
\hline & $\mathrm{CV}$ & 42.90 & 30.26 & - & - & 18.42 & - & - & - & - & 14.07 \\
\hline \multirow[t]{2}{*}{$\mathrm{J} 11 \mathrm{~K} 1$} & $\mathrm{~s}^{2}$ & 3.20 & 6.86 & 11.27 & 11.68 & - & 18.99 & - & 23.46 & - & - \\
\hline & $\mathrm{CV}$ & 43.11 & 31.75 & 27.22 & 20.94 & - & 17.69 & - & 14.89 & - & - \\
\hline \multirow[t]{2}{*}{$\mathrm{J} 12 \mathrm{~K} 1$} & $\mathrm{~s}^{2}$ & 3.25 & 6.13 & - & - & - & - & - & - & - & - \\
\hline & $\mathrm{CV}$ & 43.17 & 30.26 & - & - & - & - & - & - & - & - \\
\hline \multirow[t]{2}{*}{$\mathrm{J} 13 \mathrm{~K} 1$} & $s^{2}$ & 3.14 & 6.68 & - & 13.59 & - & - & - & - & - & - \\
\hline & $\mathrm{CV}$ & 42.75 & 31.25 & - & 22.34 & - & - & - & - & - & - \\
\hline \multirow[t]{2}{*}{$\mathrm{J} 14 \mathrm{~K} 1$} & $s^{2}$ & 3.02 & 5.87 & 11.07 & - & - & 17.61 & 17.50 & - & - & - \\
\hline & $\mathrm{CV}$ & 41.67 & 29.38 & 26.46 & - & - & 16.74 & 14.27 & - & - & - \\
\hline \multirow[t]{2}{*}{$\mathrm{J} 15 \mathrm{~K} 1$} & $\mathrm{~s}^{2}$ & 3.03 & 6.49 & - & 10.74 & 13.07 & - & - & 19.45 & - & 24.66 \\
\hline & $\mathrm{CV}$ & 41.63 & 30.41 & - & 19.65 & 17.34 & - & - & 13.20 & - & 11.97 \\
\hline \multirow[t]{2}{*}{$\mathrm{J} 16 \mathrm{~K} 1$} & $s^{2}$ & 2.98 & 5.68 & - & - & - & - & - & - & - & - \\
\hline & $\mathrm{CV}$ & 41.73 & 28.92 & - & - & - & - & - & - & - & - \\
\hline \multirow[t]{2}{*}{$\mathrm{J} 17 \mathrm{~K} 1$} & $s^{2}$ & 2.99 & 6.31 & 10.69 & 13.20 & - & 16.14 & - & - & 28.82 & - \\
\hline & $\mathrm{CV}$ & 41.94 & 30.24 & 26.07 & 21.98 & - & 16.17 & - & - & 14.35 & - \\
\hline
\end{tabular}

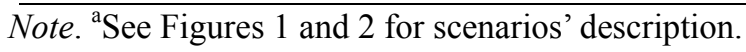


Table 14. Variance $\left(\mathrm{s}^{2}\right.$ in $\left.\mathrm{g}^{2} 10^{4}\right)$ and coefficient of variation $(\mathrm{CV}$, in percentage) for the fresh mass of fruits of $C$. annuum in different scenarios created by the exclusion of rows $(\mathrm{K})$ and columns $(\mathrm{J})$, in different experimental unit sizes for the trial carried out at the autumn-winter season

\begin{tabular}{|c|c|c|c|c|c|c|c|c|c|c|c|}
\hline \multirow{2}{*}{ Scenario $^{\mathrm{a}}$} & & \multicolumn{10}{|c|}{ Size of experimental unit in plants } \\
\hline & & 1 & 2 & 3 & 4 & 5 & 6 & 7 & 8 & 9 & 10 \\
\hline \multirow[t]{2}{*}{ J0K1 } & $\mathrm{s}^{2}$ & 2.27 & 4.84 & - & - & - & - & 21.53 & - & - & 27.17 \\
\hline & $\mathrm{CV}$ & 39.72 & 29.55 & - & - & - & - & 18.26 & - & - & 14.99 \\
\hline \multirow[t]{2}{*}{$\mathrm{J} 1 \mathrm{~K} 1$} & $\mathrm{~s}^{2}$ & 2.29 & 5.00 & - & 11.00 & - & - & - & - & - & - \\
\hline & $\mathrm{CV}$ & 39.71 & 29.39 & - & 22.07 & - & - & - & - & - & - \\
\hline \multirow[t]{2}{*}{$\mathrm{J} 2 \mathrm{~K} 1$} & $\mathrm{~s}^{2}$ & 2.02 & 4.37 & 7.32 & - & - & 16.56 & - & - & - & - \\
\hline & $\mathrm{CV}$ & 39.13 & 28.85 & 24.58 & - & - & 19.36 & - & - & - & - \\
\hline \multirow[t]{2}{*}{$\mathrm{J} 3 \mathrm{~K} 1$} & $s^{2}$ & 2.01 & 4.34 & - & 9.17 & - & - & - & 21.56 & - & - \\
\hline & $\mathrm{CV}$ & 38.75 & 28.22 & - & 21.76 & - & - & - & 16.65 & - & - \\
\hline \multirow[t]{2}{*}{$\mathrm{J} 4 \mathrm{~K} 1$} & $s^{2}$ & 2.04 & 4.41 & - & - & - & - & - & - & - & - \\
\hline & $\mathrm{CV}$ & 39.11 & 28.80 & - & - & - & - & - & - & - & - \\
\hline \multirow[t]{2}{*}{$\mathrm{J} 5 \mathrm{~K} 1$} & $s^{2}$ & 2.05 & 4.44 & 7.49 & 9.60 & 12.67 & 15.69 & - & - & - & - \\
\hline & $\mathrm{CV}$ & 39.14 & 28.45 & 24.71 & 20.62 & 19.15 & 17.94 & - & - & - & - \\
\hline \multirow[t]{2}{*}{ J6K1 } & $s^{2}$ & 2.06 & 4.52 & - & - & - & - & - & - & - & - \\
\hline & $\mathrm{CV}$ & 39.11 & 29.10 & - & - & - & - & - & - & - & - \\
\hline \multirow[t]{2}{*}{$\mathrm{J} 7 \mathrm{~K} 1$} & $\mathrm{~s}^{2}$ & 2.09 & 4.59 & - & 9.38 & - & - & 21.77 & 20.77 & - & - \\
\hline & $\mathrm{CV}$ & 39.47 & 28.95 & - & 22.06 & - & - & 18.06 & 16.36 & - & - \\
\hline \multirow[t]{2}{*}{ J8K1 } & $s^{2}$ & 2.12 & 4.66 & 7.95 & - & - & 17.31 & - & - & 29.24 & - \\
\hline & $\mathrm{CV}$ & 39.51 & 29.35 & 25.47 & - & - & 19.82 & - & - & 17.48 & - \\
\hline \multirow[t]{2}{*}{ J9K1 } & $s^{2}$ & 2.15 & 4.71 & - & 10.42 & - & - & - & - & - & - \\
\hline & $\mathrm{CV}$ & 39.42 & 28.78 & - & 21.39 & - & - & - & - & - & - \\
\hline \multirow[t]{2}{*}{$\mathrm{J} 10 \mathrm{~K} 1$} & $s^{2}$ & 2.20 & 4.77 & - & - & 13.82 & - & - & - & - & 22.94 \\
\hline & $\mathrm{CV}$ & 39.85 & 29.34 & - & - & 19.80 & - & - & - & - & 13.49 \\
\hline \multirow[t]{2}{*}{$\mathrm{J} 11 \mathrm{~K} 1$} & $s^{2}$ & 2.20 & 4.74 & 7.79 & 8.92 & - & 16.29 & - & 21.21 & - & - \\
\hline & $\mathrm{CV}$ & 39.58 & 28.50 & 24.61 & 20.97 & - & 17.69 & - & 16.11 & - & - \\
\hline \multirow[t]{2}{*}{$\mathrm{J} 12 \mathrm{~K} 1$} & $s^{2}$ & 2.15 & 4.43 & - & - & - & - & - & - & - & - \\
\hline & $\mathrm{CV}$ & 39.06 & 28.14 & - & - & - & - & - & - & - & - \\
\hline \multirow[t]{2}{*}{$\mathrm{J} 13 \mathrm{~K} 1$} & $\mathrm{~s}^{2}$ & 1.91 & 4.20 & - & 8.74 & - & - & - & - & - & - \\
\hline & $\mathrm{CV}$ & 38.02 & 27.59 & - & 19.81 & - & - & - & - & - & - \\
\hline \multirow[t]{2}{*}{$\mathrm{J} 14 \mathrm{~K} 1$} & $\mathrm{~s}^{2}$ & 1.92 & 4.31 & 7.44 & - & - & 14.57 & 19.10 & - & - & - \\
\hline & $\mathrm{CV}$ & 37.75 & 27.88 & 24.25 & - & - & 18.37 & 16.23 & - & - & - \\
\hline \multirow[t]{2}{*}{$\mathrm{J} 15 \mathrm{~K} 1$} & $\mathrm{~s}^{2}$ & 1.93 & 4.41 & - & 8.81 & 13.35 & - & - & 16.83 & - & 27.69 \\
\hline & $\mathrm{CV}$ & 37.94 & 28.24 & - & 21.15 & 19.35 & - & - & 14.59 & - & 15.02 \\
\hline \multirow[t]{2}{*}{$\mathrm{J} 16 \mathrm{~K} 1$} & $\mathrm{~s}^{2}$ & 1.98 & 4.46 & - & - & - & - & - & - & - & - \\
\hline & $\mathrm{CV}$ & 38.37 & 28.25 & - & - & - & - & - & - & - & - \\
\hline \multirow[t]{2}{*}{$\mathrm{J} 17 \mathrm{~K} 1$} & $\mathrm{~s}^{2}$ & 2.06 & 4.68 & 7.95 & 9.79 & - & 17.94 & - & - & 27.97 & - \\
\hline & $\mathrm{CV}$ & 39.14 & 29.08 & 24.89 & 20.90 & - & 18.47 & - & - & 17.07 & - \\
\hline
\end{tabular}

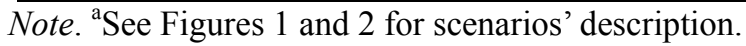

\section{Discussion}

The results observed regarding the cases of variances heterogeneity among rows in the situations where no borders were used (J0K0 scenario), agree with finding by Carpes et al. (2008) for C. pepo and Lúcio et al. (2004) for $C$. annuum. The heterogeneity of variances between rows in the trials with horticultural crops has been attributed, among other causes, to lateral openings of the greenhouse that might provide differentiated conditions of cropping on the sides of the greenhouse. Lorentz et al. (2005), and Lúcio et al. $(2008,2016)$ reported that for horticultural crops, factors such as the subjective point of harvest, occurrence of zero values in a particular 
harvest, multiple harvests and use of protected environments, are additional sources of variability, which might be influencing the variability among rows.

For C. pepo, the growing season also influenced the variability among rows, results that were also obtained by Souza et al. (2002) and Carpes et al. (2008) for this same crop. Thus, it was suggested that the seasonal season of growing can influence the productive variability of horticultural crops. In this regard, the source of variation in the heterogeneity of variances among rows from one cropping season to another, found in this work, is probably due to variations in the climatic factors between the different growing seasons. The results found in our trials with $C$. peposhow that the use of border composed of rows and columns does not provide homogenization of variances among rows.

For the trial 2 with $C$. annuum it was not possible to establish a homogenization standard of variances as a function of the borders, being this homogenization a random situation, occurring in specific situations. Thus, it is impossible to recommend the use of borders composed of rows and columns for experiments with C. annuum. This is reinforced by the results obtained for this same crop in the trial 1. It was suggested that there is no cause and effect relationship between the use of borders and the reduction of cases of variance heterogeneity among rows.

The increase in plot size provided an increase in cases of variance homogeneity among cropping rows of $C$. annuum. This behavior is explained by the fact that in the cropping row may occur areas that favor or disfavor certain plants, generating variability among that. When the size of the plot is increased, the chances of these areas being diluted among the plots increases, reducing the variability. In addition, the increase in plot size also reduces zero value cases, which contributes to the reduction of variance in the row (Lúcio et al., 2016), tending to homogenize variances among rows.

Despite the use of borders consisting of rows and/or columns had not been effective in homogenizing variances among rows, the use of a plot size consisting of two or more plants in trials with C. pepo, and ten or more plants in trials with $C$. annuum, provided homogeneity of variances among rows. Thus, it was suggested that it is possibility of using the completely randomized design in the experiments with these cultures if the plot size have an adequate size.

The observed variability among columns is characterized itself as a critical experimental problem. Generally, this variability has not been considered in experiments with horticultural crops, since the more recommended experimental design has been the randomized blocks. In this experimental design, cultivation rows parallel to the lateral openings of the greenhouse have been used as blocks mainly due to the existence of variability among that (Lúcio et al., 2004; Carpes et al., 2008).

Randomized blocks experimental design is recommended for situations where the experimental area is not homogeneous and it is possible to allocate the experimental units in homogeneous blocks (Steel et al., 1997; Storck et al., 2016). In protected environment, trials where the variances are heterogeneous among columns, the blocks composed of rows will present variance heterogeneity. This is a critical issue, since the variability within the block tends to increase the experimental error. Thus, the variability between columns will be reflected in an increase in residual variance when performing an experiment where the rows are taken as blocks.

One way to circumvent this problem would be to use the Latin square design, in which the experimental units are grouped into homogeneous rows and columns. The use of the Latin Square in protected environments, however, would generate a problem in the sense that the available experimental area would not be completely used, since the number of rows should be equal to the number of columns (Steel et al., 1997). This would happen because the number of cropping rows available is limited to the width of the environment in question and, in the case of the Latin square design, the number of columns would be limited by the number of rows. Therefore, our recommendation for protected environment trials would be to use a suitable plot size with the treatments allocated in a completely randomized experimental design.

Although there were cases where the use of borders provided homogeneous variances among columns, there were cases where the use of borders maintained or increased the proportion of cases of variance heterogeneity. Thus, it is not possible to establish a cause and effect relationship between the use of rows made up of rows and columns, with cases of heterogeneity or homogeneity of variance among columns.

For C. annuum at trial 2, the observed result allows to infer that the reductions in cases of variances heterogeneity among columns occurring in some scenarios are not due to the borders but to a combination of factors that vary according to the cropping season. In a study with C. pepo grown in different irrigation systems, Carpes et al. (2008) verified that the drip irrigation system is a source of variability in the experiment. This is 
because eventually, some dripper in the dripping tube may completely or partially clog up, causing some plants in the row to receive less water than others. Considering that in all the trials of this study the used irrigation system was the dripping, this could be one of the factors related to increasing in the variability within the rows. In order to circumvent this problem, irrigation and other cropping management should be carried out in the most homogeneous way possible, in order to not be sources of heterogeneity in the experiment.

The increase in plot size shows itself as a simple and efficient strategy to reduce the variability among rows and columns, agreeing with the results found by Lúcio et al. (2016). These results show that if the plot size is sufficiently large, the completely randomized design might be used in the experiments with $C$. pepo and $C$. annuит.

The results obtained in relation to the values of the coefficients of variation of the trials also show that the cropping season influences the productive variability of horticultural crops. The same found was also observed by Lúcio et al. (2008), Carpes et al. (2008), and Carpes et al. (2010) who also worked with horticultural crops in different growing seasons. The divergence of results between seasonal seasons shows that the lower values of variance and coefficient of variation in the spring-summer season are due to a combination of several factors and might not be repeated in another experiment at the same growing season, since the factors influencing the variability might vary even in the same growing season.

The reduction in the values of the coefficients of variation provided by the use of borders seems to be related to the reduction in the means, since the variances were little impacted. Lúcio et al. (2008), working with C. pepo in protected environment highlighted that the lateral rows in protected environment are in different conditions of temperature and soil moisture. In this way, it is possible to suppose that the reason for the smaller coefficients of variation with the use of borders made up of rows, is that these rows are in unfavorable conditions that lead to a lower production average. Thus, with the exclusion of those rows, the average of the experiment increased, providing a reduction on coefficient of variation.

Despite the reduction in the coefficients of variation with the use of borders made up of lateral rows, these were substantial and, as already discussed, were not reflected on the homogenization of rows or columns. This reduction can be reflected in an increase in the estimation of the experimental error since the number of repetitions in an experiment is closely related to the estimation of experimental error (Steel et al., 1997).

\section{Conclusions}

It was proved that there is variability among rows/columns in trials with Cucurbita pepo and Capsicum annuum in a greenhouse. The use of borders consisting of lateral rows or columns perpendicular to the sides of the greenhouses does not bring benefits in terms of reducing the coefficient of variation or reducing the cases of variability among rows or columns. Our pioneering results suggests that the use of a plot size greater than or equal to two plants for trials with $C$. pepo and ten plants with $C$. annuum, provides homogeneity of variances between rows and columns, allowing the use completely randomized design in these trials.

\section{References}

Bartlett, M. (1937). Properties of sufficiency and statistical tests. Proceedings of the Royal Society A, 160, 268-282. https://doi.org/10.1098/rspa.1937.0109

Carpes, R. H., Lúcio, A. D., Lopes, S. J., Benz, V., Haesbaert, F., \& Santos, D. (2010). Variabilidade produtiva e agrupamentos de colheitas de abobrinha italiana cultivada em ambiente protegido. Ciência Rural, 40, 264-271. https://doi.org/10.1590/S0103-84782010005000007

Carpes, R. H., Lúcio, A. D., Storck, L., Lopes, S. J., Zanardo, B., \& Paludo, A. L. (2015). Ausência de frutos colhidos e suas interferências na variabilidade da fitomassa de frutos de abobrinha italiana cultivada em diferentes sistemas de irrigação. Ceres, 55, 590-595.

Cochran, W., \& Cox, G. (1986). Experimental design (2nd ed.). New York, NY: John Wiley \& Sons.

Confederação da Agricultura e Pecuária do Brasil. (2017). Horticultura. Retrieved from http://www.cnabrasil. org.br/sites/default/files/sites/default/files/uploads/11_hortalicas.pdf

Correia, P. J., Pestana, M., Martinez, F., Ribeiro, E., Gama, F., Saavedra, T., \& Palencia, P. (2011). Relationships between strawberry fruit quality attributes and crop load. Scientia Horticulturae, 130, 398-403. https://doi.org/10.1016/j.scienta.2011.06.039

EMBRAPA. (2006). Sistema Brasileiro de classificação de solos (2nd ed.). Rio de Janeiro, RJ: EMBRAPA-SPI.

Heldwein, A., Buriol, G., \& Streck, N. (2009). O clima de Santa Maria. Ciência \& Ambiente, 38, 43-58. 
Lindemann-Zutz, K., Fricke, A., \& Stützel, H. (2016). Prediction of time to harvest and its variability in broccoli (Brassica oleracea var. italica) Part I. Plant developmental variation and forecast of time to head induction. Scientia Horticulturae, 198, 424-433. https://doi.org/10.1016/j.scienta.2015.12.023

Lorentz, L. H., Lúcio, A. D., Boligon, A. A., Lopes, S. J., \& Storck, L. (2005). Variabilidade da produção de frutos de pimentão em estufa plástica. Ciência Rural, 35, 316-323. https://doi.org/10.1590/S010384782005000200011

Lúcio, A. D., Lorentz, L. H., Boligon, A. A., \& Lopes, S. J. (2006). Variação temporal da produção de pimentão influenciada pela posição e características morfológicas das plantas em ambiente protegido. Horticultura Brasileira, 24, 31-35. https://doi.org/10.1590/S0102-05362006000100007

Lúcio, A. D., Carpes, R. H., Storck, L., Lopes, S. J., Lorentz, L. H., \& Paludo, A. L. (2008). Variância e média da massa de frutos de abobrinha-italiana em múltiplas colheitas. Horticultura Brasileira, 26, 335-341. https://doi.org/10.1590/S0102-05362008000300009

Lúcio, A. D., Mello, R. M., Storck, L., Carpes, R. H., Boligon, A. A., \& Zanardo, B. (2004). Estimativa de parâmetros para o planejamento de experimentos com a cultura do pimentão em área restrita. Horticultura Brasileira, 22, 766-770. https://doi.org/10.1590/S0102-05362004000400020

Lúcio, A. D., Nunes, L. F., Rego, F., \& Pasini, M. P. B. (2016). Relations between zero-inflated variables in trials with horticultural crops. Spanish Journal of Agricultural Research, 14, e0906. https://doi.org/10.5424/sjar/ 2016142-8175

Raji, R., Jannatizadeh, A., Fattahi, R., \& Esfahlani, M. A. (2014). Investigation of variability of apricot (Prunus armeniaca L.) using morphological traits and microsatellite markers. Scientia Horticulturae, 176, 225-231. https://doi.org/10.1016/j.scienta.2014.06.033

Searle, B., Johnstone, P., \& Reid, J. (2016). Aspects of production affecting variability in vegetable crop quality. Acta Horticulturae, 1123, 17-26. https://doi.org/10.17660/ActaHortic.2016.1123.3

Souza, M. F., Lucio, A., Storck, L., Carpes, R., Santos, P., \& Siqueira, L. (2002). Tamanho da amostra para peso da massa de frutos, na cultura da abóbora italiana em estufa plástica. Revista Brasileira de Agrociência, 8 , 123-128. https://doi.org/10.18539/cast.v8i2.441

Sprent, P., \& Smeeton, N. C. (2006). Applied nonparametric statistical methods (4th ed.). New York, NY: Chapman \& Hall.

Steel, R. G. D., Torrie, J. H., \& Dickey, D. A. (1997). Principles and procedures of statistics: A biometrical approach (3rd ed.). New York, NY: McGraw Hill Book.

Storck, L., Lopes, S. J., Estefanel, V., \& Garcia, D. C. (2016). Experimentação Vegetal (3rd ed.). Santa Maria, SM: Editora UFSM.

Webb, R. A. (1978). Variability in the components of yield of black currant cultivars. Scientia Horticulturae, 8 , 119-127. https://doi.org/10.1016/0304-4238(78)90016-X

\section{Copyrights}

Copyright for this article is retained by the author(s), with first publication rights granted to the journal.

This is an open-access article distributed under the terms and conditions of the Creative Commons Attribution license (http://creativecommons.org/licenses/by/4.0/). 